\title{
Determination of the spatial structure of vegetation on the repository of the mine "Fryderyk" in Tarnowskie Góry, based on airborne laser scanning from the ISOK project and digital orthophotomaps
}

\author{
Marta Szostak $^{1}$, Piotr Wężyk ${ }^{1}$, Marek Pająk ${ }^{2}$, Paweł Haryło ${ }^{1}$, \\ Marek Lisańczuk ${ }^{1}$ \\ ${ }^{1}$ University of Agriculture in Krakow, Faculty of Forestry \\ Institute of Forest Resources Management \\ Department of Forest Management, Geomatics and Forest Economics - Laboratory of Geomatics \\ Aleja 29 Listopada 46 , 31-425 Krakow, Poland \\ e-mail: m.szostak@ur.krakow.pl,p.wezyk@ur.krakow.pl,p.hawrylo@ur.krakow.pl \\ ${ }^{2}$ University of Agriculture in Krakow, Faculty of Forestry \\ Institute of Forest Ecology and Silviculture, Department of Forest Ecology and Reclamation \\ Aleja 29 Listopada 46, 31-425 Krakow, Poland \\ e-mail: rlpajak@cyf-kr.edu.pl
}

Received: 16 October 2014 / Accepted: 12 February 2015

\begin{abstract}
The purpose of this study was to determine the spatial structure of vegetation on the repository of the mine "Fryderyk" in Tarnowskie Góry. Tested area was located in the Upper Silesian Industrial Region (a large industrial region in Poland). It was a unique refuge habitat - Natura2000; PLH240008. The main aspect of this elaboration was to investigate the possible use of geotechniques and generally available geodata for mapping LULC changes and determining the spatial structure of vegetation. The presented study focuses on the analysis of a spatial structure of vegetation in the research area. This exploration was based on aerial images and orthophotomaps from 1947, 1998, 2003, 2009, 2011 and airborne laser scanning data (2011, ISOK project). Forest succession changes which occurred between 1947 and 2011 were analysed. The selected features of vegetation overgrowing spoil heap "Fryderyk" was determined.

The results demonstrated a gradual succession of greenery on soil heap. In 1947, $84 \%$ of this area was covered by low vegetation. Tree expansion was proceeding in the westerly and northwest direction. In 2011 this canopy layer covered almost $50 \%$ of the research area. Parameters such as height of vegetation, crowns length and cover density were calculated by an airborne laser scanning data. These analyses indicated significant diversity in vertical and horizontal structures of vegetation. The study presents some capacities to use airborne laser scanning for an impartial evaluation of the structure of vegetation.
\end{abstract}

Keywords: ALS, manual vectorization, forest succession, DTM, DSM, nDSM, LULC 


\section{Introduction}

The description which mirrors reality in the form of geoinformation should contain data about the localization of the objects and attributes; this includes descriptions of the objects and the relations between them (Talarczyk and Neroj, 2010). Availability of spatial data obtained with techniques such as photogrammetry and remote sensing nowadays provides access to objective information of the surrounding environment. A multitude of research has proven the possibility of using these geodata for environmental protection and spatial management of the natural environment, or to determine indicators that show the spatial range and structure of vegetation, including the dynamic process of forest succession (Andersen et al., 2006; Coops and White, 2003; Drzewiecki et al., 2014; Lefsky et al., 2002; Singh et al., 2012; Suzanchi and Kaur, 2011; Wężyk and de Kok, 2005). Widely used in this respect is laser scanning technology (LIDAR), which allows large-scale research to be conducted and provides detailed information allowing for the description of the topography and structure of the vegetation growing on a given surface.

Extensive research of nature showed that these geodata, including the point cloud coming from the Airborne Laser Scanning (ALS), defines the indexes referring to the structure of vegetation (Næsset, 2002; Næsset and Økland, 2002; Tompalski, 2012; Wężyk, 2008). Particular attention should be paid in constantly developing solutions which provide information on biometrical features of vegetation (Korpetta, 2010). Examples of some of the identifiable parameters using laser scanning point clouds include: the height of trees, their thickness and volume, the number of trees per unit area, the density and length of tree crowns, the area occupied by particular vegetation patches and their spatial distribution, and many other features describing the vegetation to a greater or lesser extent (Smreček and Danihelová, 2013; Wężyk, 2008).

The goal of this paper is to determine changes of the land cover classes (especially forest succession) and define selected indexes characterizing spatial structures of vegetation on the repository the mine "Fryderyk" in Tarnowskie Góry, based on the airborne laser scanning data, airborne photographs and orthophotomaps. In this aspect, the analysis of temporal and spatial changes of land cover in 1947 - 2011 was done using available images and orthophotomaps of this period. ALS data was from the ISOK project - Informatics System of the Country Protection from extraordinary threat. This project ran in Poland in 2011 with the goal of ALS point cloud data covering the whole country until 2016 ; approximately, $70 \%$ is already done.

\section{Study area}

The post-flotation spoil tip of the mine "Fryderyk" (Fig. 1) is situated in the Silesian voivodeship in the Tarnogórski District, within the administrative borders of the city of Tarnowskie Góry, which is $4 \mathrm{~km}$ south of its centre. The year most 
commonly recognized as the date of starting the mining is the year 1840. In 1912 the outflow was closed, and in 1926 the deposition of mining wastes stopped in this object. In recent years on a spoil tip, multifaceted degradation was observed such as illegal wastes deposition, increased erosion caused by people riding motorcycles, bicycles, driving all-terrain-vehicles (quads) and by uncontrolled exploitation of the rock material. In 2004 a habitat protection area was formed within the programme - NATURA 2000 - covering, among others, the repository. In 2006 in the repository area, a Cultural Park called "Hałda Popłuczkowa" (Post-Flotation Spoil Tip) was established.

The study area covered 6.64 ha. A large part of the spoil tip is a relatively even hilltop (plateau) in its central and western part. In the highest place, the repository is over $23 \mathrm{~m}$ above the surrounding area. On the hilltop, one can observe old workings from the times when the mine "Fryderyk" was in action. The lowest parts are in the south-eastern section, where the relative altitude is about $16-17 \mathrm{~m}$. The relief of this area is, however, richer than in the other parts. Characteristic elements of the spoil tip are steep slopes in its northern part, inclining as much as $40-45^{\circ}$, as well as scarps surrounding the hilltop of the repository and marking its borders. On the slopes, in particular the ones in the northern and western parts, which are most susceptive to wind and rain, the tops of withered material and erosion-caused indentations are clearly visible (Lamparska-Wieland, 1997). Rich vegetation grows on the southern and eastern parts of the spoil tip, especially the trees on the foothill of scarps which are large, because they have good humidity conditions and the finest rock material. The northern part of spoil tip and its slopes have the poorest vegetation. Clearly visible erosion processes in that part efficiently prevent the expansion of vegetation.
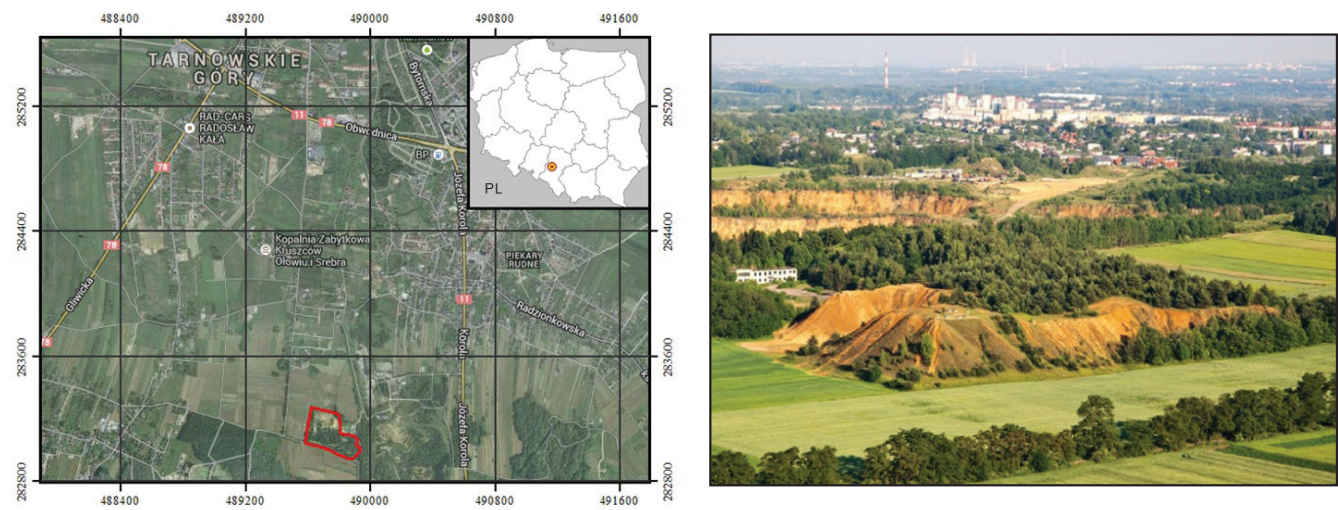

Fig. 1. Location of the study area (source: GEOPORTAL) and the view of the spoil tip from the north-western side (photo: S. Romankiewicz 2012) 


\section{Methods and materials}

To analyse vegetation changes (2D) over several decades (including mainly the course of the succession of vegetation on the spoil tip), on-screen vectorization was used. The manual vectorization process was based on the airborne photograph of 1947 (pixel size $0.37 \mathrm{~m}, \mathrm{~B} \& \mathrm{~W})$ and airborne orthophotomaps of the years: $1998(0.13 \mathrm{~m}$, RGB), 2003 (0.25 m, B\&W), 2009 (0.25 m RGB), 2011 (0.67 m, RGB). The onscreen vectorization was carried out in software ArcGIS (Esri). The final effect of the manual vectorization process was the map composition visualizing spatial distribution of the land cover classes in: 1947, 1998, 2003, 2009 and 2011.

The analysis of the orthophotomaps and airborne photographs allowed for differentiating the following land cover classes on the spoil tip:

- High vegetation - areas of tree vegetation or/and single trees, clearly distinct compared to other classes.

- Dense shrub and herbaceous vegetation - herbaceous plants and shrubs fully covering the area when they occur, so it is impossible to single out the individuals.

- Scarce shrub and herbaceous vegetation - areas like in the previous class, however the vegetation is not dense. Usually in this group there were fragments with the features of the class "sands" occurring on the border of both classes, where precise border definition for this object was difficult.

- Sands - fragments of the spoil tip not covered by any form of vegetation. Also dirt roads and paths in the study area were put into this class.

Another source of information on the study area were classified point clouds of airborne laser scanning (ALS) of 2011 from the ISOK project (format LAS, cloud density $12 \mathrm{pts} . \mathrm{m}^{2}$, source: District Centre of Surveying and Cartography). The classification of the land cover for 2011 was carried out on the integrated data, ALS data and the airborne orthophotomap. The ALS data applied in the vectorization process allowed to distinguish an additional class: Medium Vegetation (trees and shrubs of the height from 1 to $7 \mathrm{~m}$ ). ALS data also facilitated the process of the on-screen vectorization - classification of "dubious" areas, which usually included shaded places on the border of the classes.

To obtain the altitude data useful in the process of on-screen vectorization and for the assessment of the spatial (3D) structure of vegetation, a range of transformations of the initial LAS point cloud format were made. For the processing of the ALS data the following software was applied: FugroViewer (Fugro Geospatial Services) - viewing the point cloud; FUSION (R. J. McGaughey USDA Forest Service) - conversion and analysis of ALS data; LAStools pack (Rapidlasso GmbH) - transformation of ALS data.

The processing of ALS point cloud started from the reduction (cutting) of the initial file to the borders of the study area (in FUSION), and then making the Digital Terrain Model (DTM) - based on the automatic approximation of the points of the "ground" class; the Digital Surface Model (DSM) based on points from the other 
classes and normalized DSM (nDSM), where the relative altitude is determined as the difference between the absolute altitude of a given point and the place found exactly under this point on the NMT surface.

The subsequent stage of the processing of the ALS point clouds was to determine basic spatial characteristics of vegetation. The mean height of the vegetation for the whole study area was calculated in individual height classes, separately for height, medium and low vegetation. This parameter was calculated as a value of $95^{\text {th }}$ percentile of relative altitude of the ALS point cloud, indicating the height below which there are $95 \%$ points. This quantile is often used in the calculation of the height of the trees based on the airborne laser scanning data (Næsset, 2002). The percentile values were calculated in the programme FUSION with the application of algorithms contained in the tool of cloudmetrics. Also, standard deviation from the mean value of height was calculated. The spatial distribution of height was presented in the form of raster layers as well as standard deviations (Wężyk et al., 2008).

To estimate the mean of the crown base, crown length and shape of the trees on the repository, histograms of the number of ALS points (1-metre height intervals) for the class of high and medium vegetation were done. The data for the graphs was obtained based on the analysis of the normalized point cloud in the FUSION program.

The index of cover density was calculated in program FUSION using the cover function. This algorithm calculates the ALS point cloud in the area determined by the user. The program differentiated between the points reflected from the tree crowns and points penetrating inside the tree stand. By referring the total number of points "arrested" in the tree crowns to the total number of points in the tested area, a ratio is obtained, treated as the degree of cover density. The result of the calculation is the raster layer - every pixel represents the degree of cover density in the analysed area (McGaughey, 2012). The cover density in the area of the repository was calculated in different basic field sizes: $25 \mathrm{~m}^{2}$ and $225 \mathrm{~m}^{2}$, to show the differentiation of this parameter depending on the pixel size.

As well as the clouds of ALS points, the height of vegetation on the test plots was also measured. The 14 test plots (square $10 \mathrm{~m} \times 10 \mathrm{~m}$ ) located in the area of the repository were used (Derbis, 2013). The results of the traditional measurements with the altimeter (reference data; 2011) were compared with the method of remote and automated definition of height based on the ALS data (2011). The mean height of the subsequent vegetation classes for the whole study area marked as $\mathrm{H}_{\mathrm{ALS}}$ standard deviation from the mean height value as Std_dev and the variability coefficient marked as $\mathrm{Cv}$. Also, the mean height within all the areas of test plots was determined $\left(\mathrm{H}_{\mathrm{ALS}} \mathrm{T}\right)$. The results were compared to the results of field measurements of height with traditional methods $\left(\mathrm{H}_{\mathrm{T}}\right)$. The difference between $\mathrm{H}_{\mathrm{ALS}} \mathrm{T}$ and $\mathrm{H}_{\mathrm{T}}$ was determined as $\mathrm{H}_{\mathrm{DIFF}}$. 


\section{Results}

The results of the analyses of the 2D vegetation changes (1947-2011) are presented in figure 2. Analysing changes in the spatial range of vegetation on the repository (succession process), one can state that in 1947 the majority of the spoil tip was covered by dense shrub and herbaceous vegetation, mainly overgrowing the eastern part of the repository and central parts of the top plateau. Interpreting the results of the vectorization of orthophotomaps of 1998 , one should certainly notice that definitely the largest part of the spoil tip was covered by low vegetation and there was still a zone division into dense vegetation covering the hilltop and scarce vegetation on the scarps. The expansion of the high vegetation is clearly visible and goes northwards and westwards. In the period of 1998-2011, a clear expansion of trees took place at the expense of short vegetation. A very interesting phenomenon is the growth of the proportion of the class called "ground". This fact can be explained by intensive erosion processes taking place on the scarps of the repository, strengthened by anthropogenic influence and free penetration of the area (taking out the material, depositing rubbish or driving quads, riding motorcycles and bicycles).

A good overall picture referring to the differentiation of the height of vegetation on the spoil tip is given in figure 3, based on ALS data (2011). It shows the altitude of a given place (pixel) regarding the surface of the spoil tip and standard deviation from the mean height of a given vegetation class. Uneven distribution of the height of trees on the spoil tip can indicate the natural course of the process of succession or/and a significant micro-habitat differentiation of the study area. The biggest height differences occur in the class of high vegetation in the places where trees are the highest and the process of plant succession is the longest.

The results on the comparison of height determined on traditional measurements and the ALS data were presented in table 1. There were no high differences between our results and other projects regarding the height determination of ALS data (Hyyppä et al., 2004; Maltamo et al., 2004; McGaughey et al., 2004; Næsset and Økland, 2002; Węzyk et.al, 2008; Yu et al., 2004). Height of vegetation measured with the application of ALS data within the study surfaces referring to the value obtained with the use of hand terrain measurements varied by about $0.4 \mathrm{~m}$ for high vegetation, about $-0.5 \mathrm{~m}$ for medium vegetation, and $-0.2 \mathrm{~m}$ for low vegetation. 


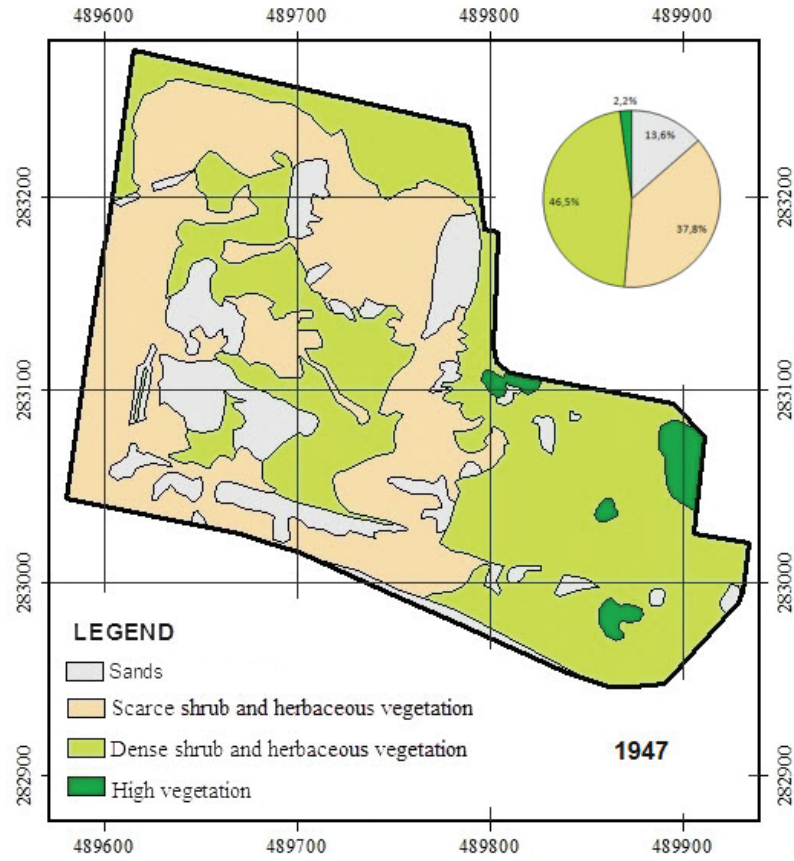

Fig. 2a. The land cover map of the mine „Fryderyk” - 1947

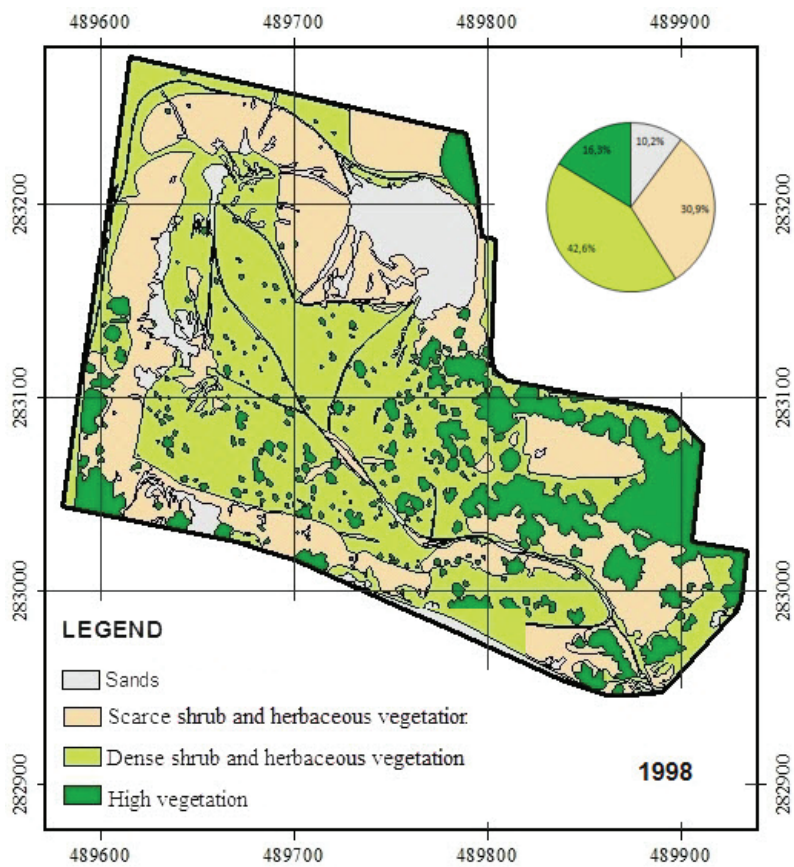

Fig. 2b. The land cover map of the mine „Fryderyk” -1998 


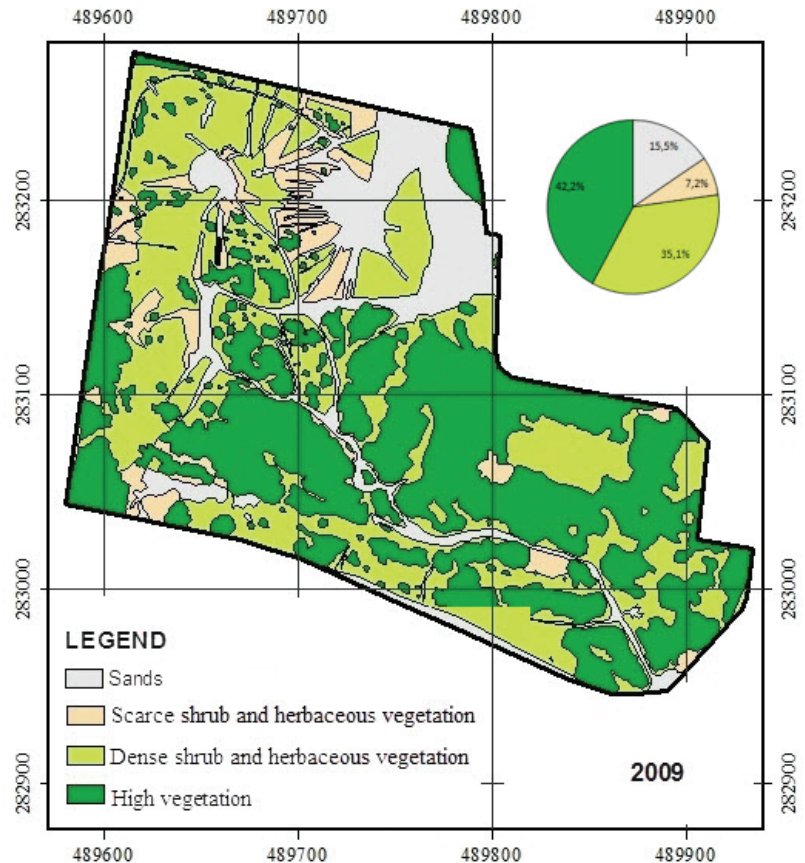

Fig. 2c. The land cover map of the mine „Fryderyk”- 2009

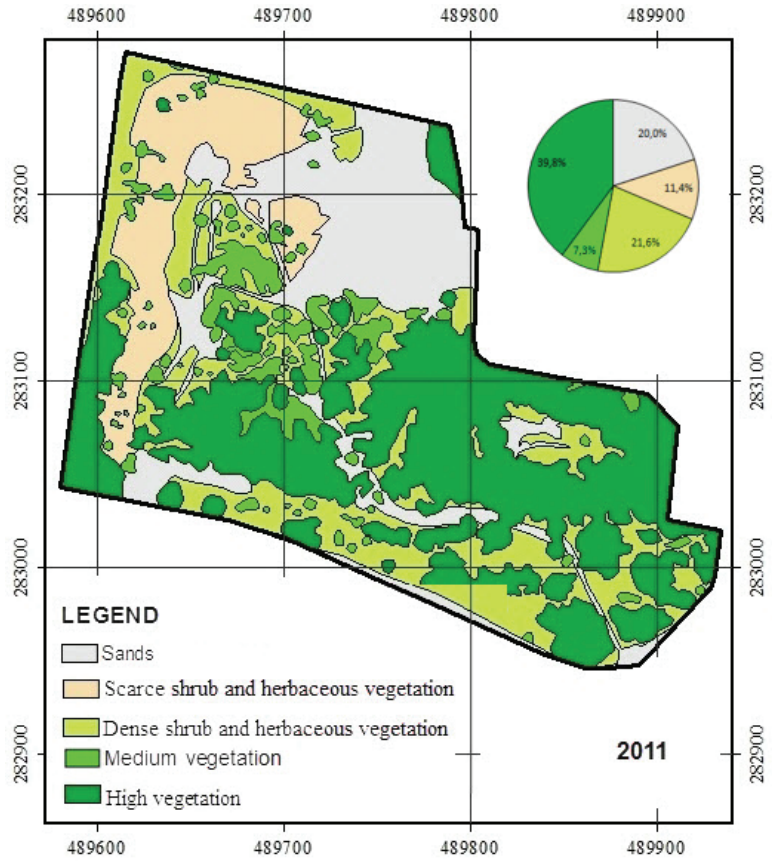

Fig. 2d. The land cover map of the mine „Fryderyk”- 2011 

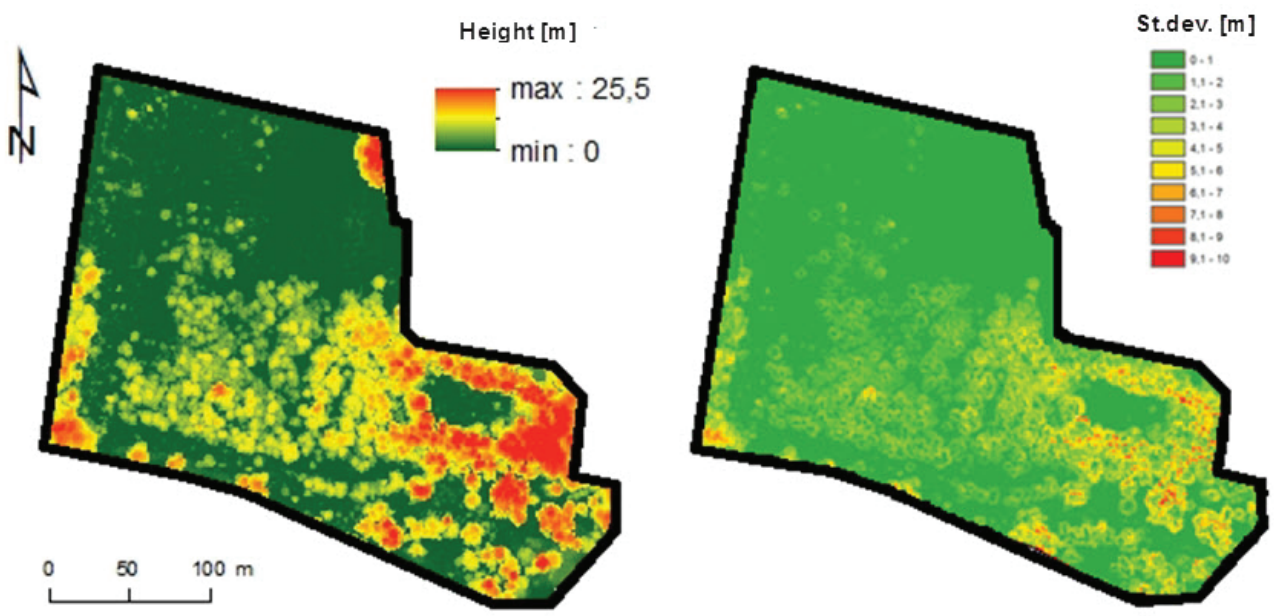

Fig. 3. Height of vegetation $\left(95^{\text {th }}\right.$ percentile) and standard deviation

Table 1. The height of vegetation (2011) - results of the traditional measurements and ALS data

\begin{tabular}{|c|c|c|c|c|c|c|}
\hline Classes & $\mathrm{H}_{\mathrm{ALS}}[\mathrm{m}]$ & $\begin{array}{c}\mathrm{Std} \_\mathrm{dev} \\
{[\mathrm{m}]}\end{array}$ & $\begin{array}{c}\mathrm{Cv} \\
{[\%]}\end{array}$ & $\begin{array}{c}\mathrm{H}_{\text {ALS_T }} \\
{[\mathrm{m}]}\end{array}$ & $\begin{array}{c}\mathrm{H}_{\mathrm{T}} \\
{[\mathrm{m}]}\end{array}$ & $\begin{array}{c}\mathrm{H}_{\text {DIFF }} \\
{[\mathrm{m}]}\end{array}$ \\
\hline High vegetation & 17.20 & 4.44 & 25.77 & 14.58 & 14.14 & 0.44 \\
\hline Medium vegetation & 5.92 & 1.49 & 25.17 & 1.96 & 2.5 & -0.54 \\
\hline Low vegetation & 0.30 & 0.08 & 26.67 & 0.23 & 0.46 & -0.23 \\
\hline
\end{tabular}
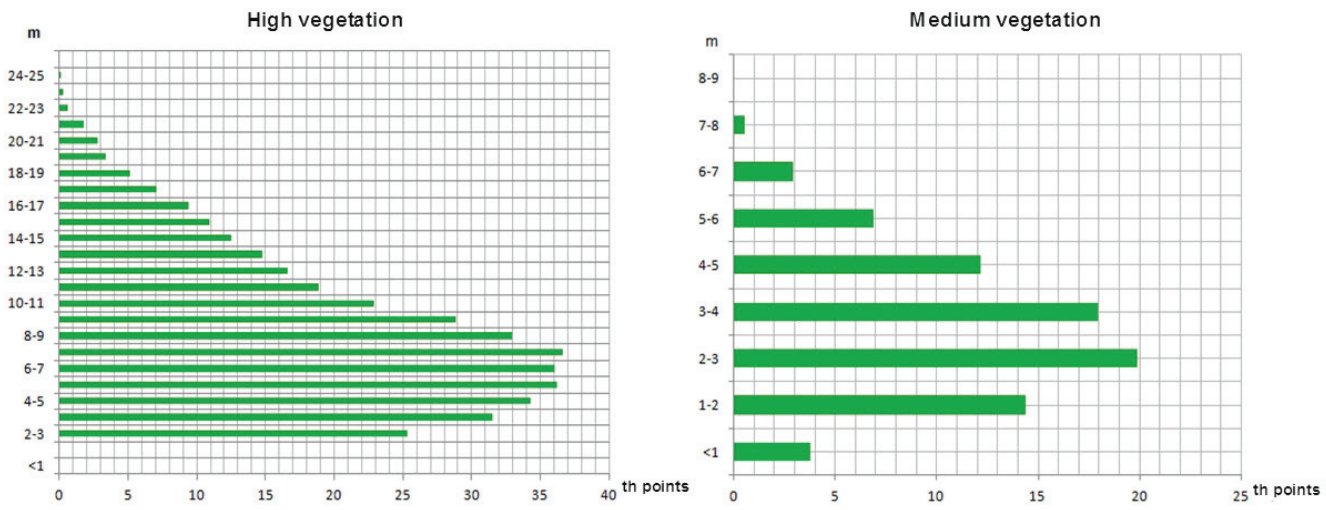

Fig. 4. Histograms of the ALS point cloud for high and medium vegetation 
To better know the shape of the tree crowns in the area of the repository, histograms were prepared for high and medium vegetation (Fig. 4). Based on the analysis of histograms, the value of about $2 \mathrm{~m}$ and $1 \mathrm{~m}$ can be accepted as the mean height of the tree crown base, for class "high vegetation" and "medium vegetation", respectively. Referring this value to the mean height, one can estimate the mean length of the tree crown in the study area. On the sections it is clearly visible that the tree crowns are based low, which was also confirmed by the field study visit.

Figure 5 presents the differentiation of degree covering the surface of the repository by the crowns of the trees (cover density), depending on the accepted size of the basic field. The colours show the degree of the compactness in a given place and a single pixel symbolizes the size of the area for which the index was calculated. The greatest degree of compactness occurs in the eastern and western part of the spoil tip, where the process of succession is the longest. The trees in this part are the oldest and reach the largest size. Tree vegetation growing on the central hilltop is characterized by a moderate degree of compactness.
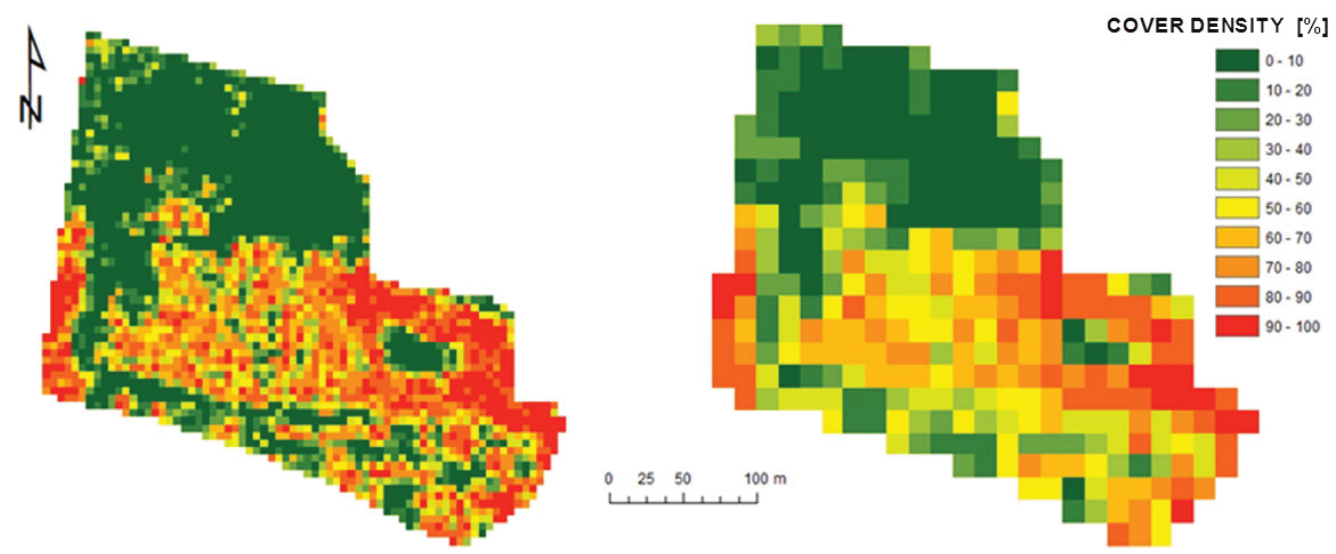

Fig. 5. Cover density: a) pixel $5 \times 5 \mathrm{~m} \mathrm{~b}) 15 \times 15 \mathrm{~m}$

\section{Conclusions}

Multi-direction analysis of the collected materials showed a significant differentiation of the spatial structure of vegetation on the repository of the mine "Fryderyk" in Tarnowskie Góry. This diversity is visible in the surface size (2D), the vertical vegetation structure (3D) and in the time dimension (4D). The differentiated plots of vegetation do not form clear borders and are unevenly distributed in the area of the whole repository. Differentiated vertical structure of vegetation indicate a long-lasting natural process of succession in the area of repository. The integrated data coming from the airborne laser scanning the ISOK project and airborne orthophotomaps in the process of screen vectorization allowed wider and more precise definition of 
the spatial structure of vegetation than in case of the work on the orthophotomaps alone. The application of the processed ALS data allowed objective and relatively accurate assessments of the spatial structure of vegetation overgrowing spoil tip. The features defined based on available materials can indicate a large differentiation of microhabitats and significant anthropogenic influence on the spatial structure and the development of the vegetation on the spoil tip.

Currently functioning remote sensing technologies and large resources of geoinformation tools allow a remote research of nature including the dynamic process of forest succession (Bergen and Dronova, 2007; Szostak et al., 2014). They allow the definition of many indexes characterising the vegetation in various aspects (Alberti et al., 2013; Pirotti, 2011; Wężyk et al., 2013). These indicators are often defined for the needs of planning and the inventory and mapping plant associations. The use of spatial data obtained with different methods and originating from different periods of time offers the possibilities of monitoring changes taking place in the environment. Due to the use of the data from airborne laser scanning, objective and exact assessments of many biometric features of vegetation connected with the spatial distribution of the point cloud is possible. The most important characteristics of the tree stand possible to be defined based on the data of the airborne laser scanning are: height of the trees, the level of compactness (density, stocking) and the length of the tree crown, the number of trees per area unit, as well as the quality and vitality of tree stands. Geoinformation technologies contain a great potential to carry out large-area studies of the spatial vegetation structure.

\section{Acknowledgments}

The article is based on own research conducted at the Faculty of Forestry, University of Agriculture in Krakow.

\section{References}

Alberti, G., Boscutti, F., Pirotti, F., Bertacco, C., De Simon, G., Sigura, M., Cazorz, F. and Bonfanti, P. (2013). A LiDAR-based approach for a multi-purpose characterization of Alpine forests: an Italian case study. iForest. 6, 156-168. Doi: 10.3832/ifor0876-006

Andersen H. E., Reutebuch, S. E. and McGaughey, R. J. (2006). A rigorous assessment of tree height measurements obtained using airborne lidar and conventional field methods. Canadian Journal of Remote Sensing, 32, 355-366.

Bergen, K.M. and Dronova, I. (2007). Observing succession on aspen-dominated landscapes using a remote sensing-ecosystem approach. Landscape Ecology 22, 1395-1410.

Coops, N. C. and White, J. D. (2003). Modeling Forest Productivity Using Data Acquired Through Remote Sensing. [In] M. A. Wulder and S. E. Franklin (eds), Remote Sensing of Forest Environments, Springer US, (pp. 411-431). DOI:10.1007/978-1-4615-0306-4_15

Derbis, P. (2013). Proces lasotwórczy na terenach antropogenicznych na przykładzie hałdy popłuczkowej kopalni „Fryderyk” w Tarnowskich Górach. Praca magisterska, UR Kraków. 
Drzewiecki, W., Wężyk P., Pierzchalski, M. and Szafrańska, B. (2014). Quantitative and Qualitative Assessment of Soil Erosion Risk in Małopolska (Poland), Supported by an Object-Based Analysis of High-Resolution Satellite Images. Pure Appl. Geophys., 171(6), 867-895. DOI: 10.1007/s00024013-0669-7

Hyyppä, J., Hyyppä, H., Litkey, P., Yu, X., Haggrén, H., Rönnholm, P., Pyysalo, U., Pitkanen, J. and Maltamo M. (2004). Algorithms and methods of airborne laser-scanning for forest measurements. Thies M., Koch B., Spiecker H. i Weinacker H. (eds.): Laser-Scanners for Forest and Landscape Assessment: Proceedings of the ISPRS Working Group VIII/2. Freiburg, Germany. International Archives of Photogrammetry, Remote Sensing, and the Spatial Information Sciences. XXXVI-8/W2.

Lefsky, M. A., Cohen, W. B., Parker, G. G. and Harding, D. J. (2002). Lidar Remote Sensing for Ecosystem Studies. BioScience, 52/1, 19-30.

Korpetta, D., (2010). Wprowadzenie do geomatyki leśnej. Geomatyka w Lasach Państwowych, Część I. Podstawy. Centrum Informacyjne Lasów Państwowych, Warszawa, s. 49-52.

Lamparska-Wieland, M., (1997). Hałda pachnąca macierzanką. Wydawnictwo Krajoznawca Górnośląski, Katowice.

Maltamo, M., Mustonen, K., Hyyppa J., PitkaNen, J. and Yu, X. (2004). The accuracy of estimating individual tree variables with airborne laser scanning in a boreal nature reserve. Canadian Journal of Forest Research, 34 (9), 1791-1801.

McGaughey, R. J. (2012). Fusion/ldv: Software for lidar data analysis and visualization. Software manual. USDA Forest Service. Pacific Northwest Research Station.

Mcgaughey, R. J., Carson, W., Reutebuch, S. and Andersen, H.-E. (2004). Direct measurement of individual tree characteristics from lidar data. Proceedings of the Annual ASPRS Conference. Denver. American Society of Photogrammetry and Remote Sensing.

Næsset, E. and Økland, T. (2002). Estimating tree height and tree crown properties using airborne scanning laser in a boreal nature reserve. Remote Sensing of Environment, 79, 105-115.

Næsset, E., (2002). Predicting forest stand characteristics with airborne scanning laser using a practical two-stage procedure and field data. Remote Sensing of Environment, 80, 80-99.

Pirotti, F. (2011). Analysis of full-waveform LiDAR data for forestry applications: a review of investigations and methods. iForest, 4: 100-106. DOI: 10.3832/ifor0562-004

Singh,K., Vogler, J., Shoemaker, D. and Meentemeyer, R. (2012). LiDAR-Landsat data fusion for large-area assessment of urban land cover: Balancing spatial resolution, data volume, and mapping accuracy. ISPRS Journal of Photogrammetry and Remote Sensing, 74, 110-121.

Smreček, R. and Danihelová, Z. (2013). Forest stand height determination from low point density airborne laser scanning data in Roznava Forest enterprise zone (Slovakia). iForest, 6, 48-54. DOI: 10.3832/ifor0767-006

Suzanchi, K. and Kaur, R., (2011). Land use land cover change in National Capital Region of India: A remote sensing \& GIS-based two decadal spatial-temporal analyses. Procedia - Social and Behavioral Sciences, 21, 212-221.

Szostak, M., Wężyk, P. and Tompalski, P. (2014). Aerial Orthophoto and Airborne Laser Scanning as Monitoring Tools for Land Cover Dynamics: A Case Study from the Milicz Forest District (Poland). Pure and Applied Geophysics, 171 (2014), 6, 857-866, DOI: 10.1007/s00024-013-0668-8

Talarczyk, A. and Neroj, B. (2010). Źródła danych dla systemu informacji przestrzennej. Geomatyka w Lasach Państwowych. Centrum Informacyjne Lasów Państwowych, Warszawa, s. 113-129.

Tompalski, P. (2012). The use of 3D spatial indices for urban vegetation analysis based on airborne laser scanning data. Archives of Photogrammetry, Cartography and Remote Sensing, 23, 443-456.

Wężyk, P., (2008). Modeling of the point cloud from laser scans in tree crowns. Archives of Photogrammetry, Cartography and Remote Sensing, 18, 685-695.

Wężyk, P. and de Kok, R. (2005). Automatic mapping of the dynamics of forest succession on abandoned parcels in south Poland. In: Strobl et al. (Eds.) Angewandte Geoinformatik 2005. Herbert Wichman Verlag. Heidelberg: 774-779, ISBN 3-87907-244-4 
Wężyk, P, Szostak, M. and Tompalski, P. (2013). Use of Airborne Laser Scanning Data for a Revision and Update of a Digital Forest Map and its Descriptive Database: A Case Study from the Tatra National Park. The Carpathians: Integrating Nature and Society Towards Sustainability, Part IV, pp. 615-627, Springer Berlin Heidelberg, DOI: 10.1007/978-3-642-12725-0_43

Wężyk, P., Tompalski, P., Szostak, M., Glista, M. and Pierzchalski, M. (2008). Describing the selected canopy layer parameters of the Scots pine stands using ALS data. 8th international conference on LiDAR applications in forest assessment and inventory. SiliviLaser 2008, Edinburgh, s. 636-645.

Yu, X., Hyyppa J., Kaartinen, H. and Maltamo, M. (2004). Automatic detection of harvested trees and determination of forest growth using airborne laser scanning. Remote Sensing of Environment Vol: 90 (4), 451-462.

\title{
Określenie struktury przestrzennej roślinności na zwałowisku kopalni "Fryderyk" w Tarnowskich Górach w oparciu o dane z lotniczego skanowania laserowego z projektu ISOK oraz cyfrowe ortofotomapy
}

\author{
Marta Szostak$^{1}$, Piotr Wężyk ${ }^{1}$, Marek Pająk² ${ }^{2}$ Paweł Haryło ${ }^{1}$, Marek Lisańczuk ${ }^{1}$ \\ ${ }^{1}$ Uniwersytet Rolniczy w Krakowie, Wydział Leśny \\ Instytut Zarządzania Zasobami Leśnymi \\ Zakład Urządzania Lasu, Geomatyki i Ekonomiki Leśnictwa - Laboratorium Geomatyki \\ Aleja 29 Listopada 46, 31-425 Kraków \\ e-mail: m.szostak@ur.krakow.pl; p.wezyk@ur.krakow.pl; p.hawrylo@ur.krakow.pl; lisekmgz@interia.pl \\ ${ }^{2}$ Uniwersytet Rolniczy w Krakowie, Wydział Leśny \\ Zakład Ekologii Lasu i Rekultywacji, Instytut Ekologii i Hodowli Lasu \\ Aleja 29 Listopada 46, 31-425 Kraków \\ e-mail: rlpajak@cyf-kr.edu.pl
}

\section{Streszczenie}

Celem badań była ocena struktury przestrzennej roślinności porastającej zwałowisko odpadów kopalni "Fryderyk" w Tarnowskich Górach, położone na północnym skraju Górnośląskiego Okręgu Przemysłowego. Teren, na którym znajduje się zwałowisko należy do sieci Natura 2000 (PLH 240008). Głównym aspektem poruszanym w opracowaniu było określenie możliwości wykorzystania ogólnie dostępnych geodanych dla opracowywania map pokrycia i użytkowania terenu zwałowiska oraz określenia struktury roślinności na tym obszarze. Analizowane materiały to zdjęcia i ortofotomapy lotnicze z lat: 1947, 1998, 2003, 2009, 2011 oraz dane z lotniczego skanowania laserowego (z projektu ISOK, 2011). Efektem opracowania było określenie charakterystyki przestrzennej roślinności na zwałowisku kopalni "Fryderyk". Analizy wykazały stopniową ekspansję roślinności na powierzchni hałdy. W 1947 roku 84\% powierzchni terenu badań pokryta była przez roślinność niską a w roku 2011 roślinność wysoka zajmowała już około $50 \%$ obszaru zwałowiska. Analizy wykazały znaczne zróżnicowanie w poziomej i pionowej strukturze roślinności. W opracowaniu przedstawiono możliwości wykorzystania danych z lotniczego skanowania laserowego dla obiektywnej oceny struktury roślinności. 